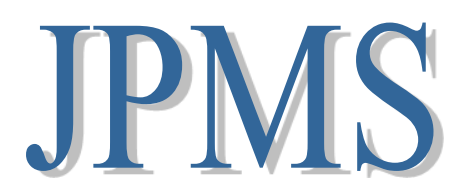

Jurnal Pengabmas Masyarakat Sehat

ARTIKEL HASIL PENGABDIAN KEPADA MASYARAKAT

URL artikel: http://ejournal.poltekkes-denpasar.ac.id/index.php/JPMS/article/view/jpms1409

\title{
Upaya Deteksi Dini Risiko Tinggi Kehamilan Ditentukan Oleh Pengetahuan Dan Pemeriksaan Kehamilan Di Pulau Osi
}

\author{
Arindiah Puspo Windari ${ }^{1 k}$; Sri Ayu Lohy ${ }^{1}$ \\ ${ }^{1}$ Sekolah Tinggi Ilmu Kesehatan Maluku Husada, DIII Kebidanan \\ Email penulis korespondensi $\left({ }^{\mathrm{K}}\right)$ : arindiah7@gmail.com
}

\begin{abstract}
The most common cause of maternal death is bleeding (30.3\%), followed by hypertension in pregnancy $(27.1 \%)$, infection (7\%). Other causes, 45\%, are quite large, including non-obstetric causes. High maternal mortality is also caused by the high number of unexpected pregnancies. Approximately $65 \%$ of pregnancies still occur because "4 too" associated with pregnancies "too young (less than 20 years)," too old: (more than 35 years), "too often (pregnancy interval less than 2 years," too many"(more than 3 children). Most maternal deaths can be prevented if adequate treatment is provided in health care facilities. Time and transportation factors are very decisive in referring to high-risk cases. Therefore, detection of risk factors in mothers is good by personnel. Health and society is one of the important efforts in preventing death and morbidity. To avoid the risk of complications in pregnancy and childbirth, every pregnant woman needs at least 4 antenatal care, namely once in the first trimester (012 weeks gestation), one times in the second trimester (12-24 weeks of gestation), and twice in the second trimester third steer (24 weeks gestation until delivery).
\end{abstract}

Keywords: Early Detection Of High Risk Pregnancy, Pregnancy Test.

\section{Pendahuluan}

World Health Organization (WHO) menyatakan bahwa kematian ibu di dunia akibat komplikasi selama kehamilan dan persalinan pada tahun 2017 diperkirakan sekitar 810 kasus. Pada tahun 2000 sampai dengan 2017 terjadi penurunan rasio AKI di seluruh dunia sebesar 38\%). WHO juga menyatakan $94 \%$ dari jumlah kematian ibu secara global terjadi di negara yang berpenghasilan rendah dan menengah. ${ }^{(1)}$

Di Indonesia kematian ibu akibat komplikasi kehamilan atau persalinan setiap tahunnya diperkirakan sebesar 20.000 ibu meninggal dari lima juta kelahiran. AKI di Indonesia disebabkan beberapa faktor. Faktor penyebabnya dibagi menjadi dua yaitu faktor penyebab langsung dan penyebab tidak langsung. Faktor penyebab langsung AKI di Indonesia masih didominasi oleh perdarahan (28\%), eklampsia (24\%), infeksi (11\%), partus lama (5\%), aborsi (5\%) dan lain-lain (27\%), yang di dalamnya terdapat juga penyulit pada masa kehamilan dan persalinan. Sedangkan faktor tidak langsung penyebab AKI dikarenakan banyaknya kasus tiga terlambat dan empat terlalu. ${ }^{(2)}$ 
Pengetahuan merupakan hasil dari tahu, dan ini terjadi setelah orang melakukan pengindraan terhadap suatu objek tertentu. Pengindraan terjadi melalui panca indra manusia, yakni indra penglihatan, pendengaran, penciuman, rasa dan raba. Sebagian besar pengetahuan manusia diperoleh melalui mata dan pendengaran. Pengetahuan merupakan domain yang paling penting untuk terbentuknya tindakan seseorang, maka dari itu perilaku yang didasari dengan pengetahuan dan kesadaran akan bertahan lama dibandingkan perilaku yang tidak didasari ilmu pengetahuan dan kesadaran. Pengetahuan atau kognitif merupakan domain yang sangat penting dalam membentuk tindakan seseorang. ${ }^{(3)}$

Penyebab kematian ibu terbanyak masih di dominasi perdarahan (30.3\%), disusul hipertensi dalam kehamilan (27.1\%), infeksi (7\%), Penyebab lain-lain 45\% cukup besar termasuk di dalamnya penyebab penyakit non obstetric. Kematian maternal yang tinggi juga disebabkan oleh tingginya angka kehamilan yang tidak diharapkan. Lebih kurang 65\% kehamilan masih terjadi karena "4 terlalu" yang berhubungan dengan kehamilan "terlalu muda (kurang dari 20 tahun), "terlalu tua: (lebih dari 35 tahun),"terlalu sering (jarak kehamilan kurang dari 2 tahun, "terlalu banyak" (lebih dari 3 anak). Sebagian besar kematian ibu dapat dicegah apabila mendapat penanganan yang adekuat di fasilitas pelayanan kesehatan. Faktor waktu dan transportasi merupakan hal yang sangat menentukan dalam merujuk kasus risiko tinggi. Oleh karenanya deteksi faktor risiko pada ibu baik oleh tenaga kesehatan maupun masyarakat merupakan salah satu upaya penting dalam mencegah kematian dan kesakitan. Untuk menghindari risiko komplikasi pada kehamilan dan persalinan, setiap ibu hamil memerlukan asuhan antenatal sebanyak minimal 4 kali, yaitu satu kali pada trimester pertama (usia kehamilan 0-12 minggu), satu kali pada trimester kedua (usia kehamilan 12-24 minggu), dan dua kali pada trimester ketiga (usia kehamilan 24 minggu sampai persalinan). ${ }^{(4)}$

Berdasarkan studi pendahuluan di Puskesmas Mungka pencapaian deteksi dini resiko tinggi oleh nakes dari Januari sampai Juni 2017 sebanyak 44 orang, sedangkan pencapaian pada juli 2017 sebanyak 5 orang, jadi pencapaian kumulatif dari Januari-Juli 2017 sebanyak 49 orang $(39,84 \%)$. Hal ini menunjukkan masih rendahnya pencapaian target deteksi dini resiko tinggi ibu hamil. Berdasarkan hasil wawancara dengan salah satu bidan di puskesmas mengatakan ibu hamil risiko tinggi banyak disebabkan oleh riwayat obstetri jelek seperti pertolongan persalinan secara section caesarea dan jarak kehamilan kurang dari 2 tahun, kemudian masih banyaknya kehamilan di usia muda akibat tingginya angka pernikahan.

\section{Metode Pengabdian}

Kegiatan pengabdian kepada masyarakat dilaksanakan di Pulau Osi, pada bulan Februari 2019. Sasaran dari kegiatan pengabdian masyarakat ini adalah para ibu hamil trimester I yang berada di lokasi penelitian. Kegiatan pengabdian ini berupa penyuluhan mengenai upaya deteksi dini risiko tinggi kehamilan menggunakan media leaflet, laptop, LCD, kuesioner dan speaker. Pengumpulan data 
dilakukan secara observasional dengan teknik pengumpulan data yang digunakan adalah teknik sampling aksidental yaitu siapa saja yang secara kebetulan bertemu dengan peneliti dapat digunakan sebagai sampel penelitian sesuai dengan kriteria inklusi yaitu ibu hamil yang bersedia diteliti dan kriteria eksklusi yaitu ibu hamil yang memiliki rekam medis yang kurang lengkap. Dalam kegiatan pengabdian masyarakat ini pengolahan dan analisis data menggunakan analisis univariat, hasil kuesioner yang didapatkan akan di tabulasi kemudian di analisis secara manual dan dibuatkan pembahasan.

\section{Hasil dan Pembahasan}

\section{A. Hasil}

\section{Hasil Pre-test dan Post-test Pengetahuan Tentang Deteksi Dini Risiko Tinggi Kehamilan}

Dari hasil data penelitian menunjukan bahwa adanya peningkatan pengetahuan ibu hamil tentang deteksi dini risiko kehamilan yaitu sebesar $64,7 \%$. Pengetahuan ibu hamil mengenai risiko tinggi kehamilan saat pre-test sebesar $41,2 \%$ setelah dilakukan penyuluhan tentang deteksi dini kehamilan pengetahuan ibu hamil mendapatkan pemahaman dan pengetahuan sehingga nilai post-test naik yaitu sebesar 64,7\%. Data selengkapnya dapat dilihat pada tabel 1.

Tabel 1. Hasil Pre-test dan Post-test Pengetahuan Tentang Deteksi Dini Risiko Tinggi Kematian

\begin{tabular}{ccccccc}
\hline \multirow{2}{*}{ No } & \multicolumn{3}{c}{ Pre-test } & \multicolumn{3}{c}{ Post-test } \\
\cline { 2 - 7 } & Pengetahuan & $\mathrm{f}$ & $\%$ & Pengetahuan & $\mathrm{f}$ & $\%$ \\
\hline 1 & Baik & 7 & 41,2 & Baik & 11 & 64,7 \\
2 & Kurang & 10 & 58,8 & Kurang & 6 & 35,3 \\
\hline & Jumlah & 17 & 100,0 & Jumlah & 17 & 100,0 \\
\hline
\end{tabular}

\section{B. Pembahasan}

Berdasarkan data tersebut menunjukan bahwa semakin baik pengetahuan ibu hamil tentang pemeriksaan deteksi dini risiko tinggi kehamilan maka semakin tinggi pula kemampuan ibu dalam melakukan deteksi dini risiko tinggi kehamilan. Hal ini didukung oleh penelitian yang dilakukan di Pulau Osi adalah sama yakni ibu hamil yang terpapar informasi tentang tanda bahaya mampu melakukan deteksi dini perdarahan pasca persalinan dengan baik dibandingkan dengan ibu hamil yang tidak terpapar informasi tanda bahaya. Kemudahan untuk memperoleh suatu informasi akan mempercepat seseorang untuk memperoleh pengetahuan yang baru. ${ }^{(3)}$

Pengetahuan tentang manfaat deteksi dini risiko tinggi pada kehamilan menyebabkan seorang ibu hamil mempunyai sikap yang positif dan akan memengaruhi ibu untuk melakukan deteksi dini risiko tinggi kehamilan dan pemeriksaan antenatal care sedini mungkin ke petugas kesehatan. Hal ini membuktikan betapa pentingnya suatu kehamilan dilakukan deteksi dini risiko kehamilan. Suatu kehamilan selalu dapat menyebabkan kemungkinan adanya risiko rendah maupun tinggi yang akan berdampak adanya penyulit selama persalinan dan nifas sehingga berisiko terjadi kematian. Adanya 
deteksi dini risiko tinggi memudahkan melakukan perencanaan pada kehamilan dan persalinan ibu sesuai tingkatan resiko yang dialami.

\section{Simpulan dan Saran}

Hasil pengabdian masyarakat ini menunjukkan adanya peningkatan pemahaman dan pengetahuan ibu mengenai deteksi dini risiko kehamilan ke arah yang lebih positif, hal ini akan memengaruhi ibu hamil untuk melakukan deteksi dini dengan melakukan pemeriksaan antenatal care ke petugas kesehatan lebih rutin. Sehingga dukungan tenaga kesehatan merupakan determinan yang paling penting menentukan dalam upaya deteksi dini risiko tinggi kehamilan. Diharapkan kepada tenaga kesehatan untuk memberikan konseling mengenai upaya deteksi dini risiko tinggi kehamilan dan mengajarkan serta memotivasi ibu hamil untuk bisa melakukan deteksi dini resiko tinggi kehamilan.

\section{Daftar Pustaka}

1. World Health Organization. Maternal Mortality. 2019

2. Yadav, R. K., Swamy, \& Binjade, B. Knowledge and Practice of Anemia among Pregnant Women Attending Antenatal Clinic in Dr. Prabhakar Kore Hospital, KarnatakaA Cross Sectional Study. IOSR Journal Of Dental And Medical Sciences, 2014. 13(4), 74-80. https://doi.org/10.9790/085313477480

3. Notoatmodjo S (2003). Pendidikan dan Perilaku Kesehatan. Jakarta : Rineka Cipta

4. Kementerian Kesehatan Republik Indonesia. Petunjuk Teknis Penggunaan Buku Kesehatan Ibu dan Anak. Jakarta: Depkes dan JICA.2015

Website:kesga.kemkes.go.id/images/pedoman/JUKNIS\%20BUKU\%20KIA\%202016. Pdf 